\title{
Jesus and the Woman of Samaria (John 4:7b-15). From the Heritage of Tradition to the Mystery of Faith
}

\author{
PIOTR KOT \\ Pontifical Faculty of Theology in Wrocław \\ e-mail: father.kefa@gmail.com \\ ORCID:0000-0001-6583-0601
}

\begin{abstract}
The dialogue between Jesus and the woman of Samaria, which is related in detail by the author of the fourth gospel, focuses on the sign of Jacob's well and the living water in its first part (4:7b-15). The climax of this section combines the well, the gift of God and the identity of Jesus. By way of allusion, Jesus leads the woman to the recognition of His person's mystery. If readers wish to comprehend the meaning of this conduct, they cannot limit themselves only to the biblical story of the patriarch Jacob. They must consider the Targum traditions. Only thus is it possible to understand how a woman of Samaria could recognize the mystery of Jesus, a Jew. Setting the story in the cultural context sheds light on the author's intentions behind the inclusion of the narrative of 4:1-42 in Corpus Johanneum. This is important in relation to the land of Samaria which was then inhabited by people who varied in terms of ethnicity and religion. The woman whom Jesus met at Jacob's well is described in such a way as to represent all Samaritans: descendants of proto-Samaritans and immigrant heathens. All of them were invited to draw from the source of salvation opened up by Jesus Christ.
\end{abstract}

Keywords: John 4:1-42, Samaritan woman, Targum, Jacob's well, living water, Samaria, Messiah

$\mathrm{T}$ he majority of exegetes agree that the Gospel of John is deeply rooted in Second Temple Judaism. This aspect is significant in relation to the diachronic method, especially for the attempt to reconstruct the text editing process (Redaktionsgeschichte) and the history of tradition (Traditionsgeschichte). The correct determination of Sitz im Leben allows the readers of the Fourth Gospel (FG) to interpret particular events in line with their cultural and religious context and, which is crucial from the vantage point of synchronic methods, it widens the perspective when the individuals in the narrative are characterised. Thus, the reader gains insight into the deeper theological layers of FG.

The above premises make it necessary for the interpreters of the Gospel of John to use various methods of exegesis. This approach is adopted, e.g. by Frédéric Manns who postulates the application of the comparative method to 
the study of FG. ${ }^{1}$ Thus, it is possible to delve into the prehistory of the text, to better appreciate the cultural background, including the Jewish background (diachronic methods) and to reveal the internal dynamics of the narrative units (synchronic methods). Frédéric Manns indicates that the interpretation of FG in the context of Judaism in the transitional period broadens the cultural horizon in which the text emerged and sheds additional light on the exegesis of the Church Fathers. $^{2}$

The grounds for this approach can be seen clearly with reference to the description of the encounter between Jesus and the woman of Samaria (John 4:1-42). This passage acquires a deeper theological significance only when it is interpreted simultaneously on literary (structure), semantic, cultural and narrative levels, from the study of microstructures within the pericope and its semantic features through the analysis of the combination of events and protagonists (the narrative approach) to the identification of structural and theological connections with the entire FG. ${ }^{3}$

This article will not focus on each of the above elements and the analysis will not cover the entire passage. In general, we will delve into the characterization of the woman of Samaria in the religious context and we will study Jesus' strategy in guiding her to recognise His messianic identity. Due to the peculiar structure of the entire passage, we will limit our analysis to the introductory dialogue $(4: 7 \mathrm{~b}-15)$ which forms the "revelatory part" along with the subsequent section (4:16-26). ${ }^{4}$ The $4: 7 b-26$ section evolves narratively and intensifies the amplitude of the story until the climax in verses 20-26. It is the turning point of the whole narrative $(4: 1-42){ }^{5}$

1 F. Manns, L'Evangile de Jean à la lumière du Judaïsme (SBFA 33; Jerusalem: Franciscan Printing Press 1991) 7.

2 Manns, L'Evangile, 8.

3 The various approaches to John 4:1-42 are presented in detail by Bogusław Górka (Jezus i Samarytanka (J 4,1-42). Historia i inicjacja [Kraków: WAM 2008]).

4 A clear structure of the pericope is presented by Charles Hudry-Clergon ("De Judée en Galilée. Étude de Jean 4,1-45," NRT 113 [1981] 830) who postulates the concentric composition of John 4:1-45. In his opinion, the entire narrative reaches the climax in 4:20-26: "Worship, true worshippers. The central part (baptism, water springing up from Jesus' side, all in One)." The revelatory narrative is analysed by Daniel Marguerat and Yvan Bourquin (Per leggere i racconti biblici. La Bibbia si racconta. Iniziazione all'analisi narrativa, 2 ed. [Roma: Edizioni Borla 2011] 67-68).

5 When writing about the development and direction of the story, Janusz Kręcidło (Nowe życie uczniów Jezusa. J 21 jako owoc eklezjologicznej relektury J 1-20 we wspólnocie Umiłowanego Ucznia [RiSB 33; Warszawa: Vocatio 2009] 107) refers to various literary theories since Aristotle to point out that the story told in the Gospel of John is "intricately constructed by the author (...), and it has a pertinent beginning, a well-planned development and the conclusion which is the direct and indirect result of all the events described by the author. Furthermore, the characterization of the protagonists, repetitions and the ongoing intrigue lead the reader to the climax of the narrative." Microstructures of the particular episodes should display analogies with the macrostructure of the entire FG. Each narrative unit, regardless of its length, should be properly structured (beginning, middle, end) and formed according to the three types of mimesis: mimesis of action (the structure of events, i.e. the story), mimesis moral characters in the story, mimesis of the intellect of the characters. 
The entire dialogue between Jesus - a Jew - and the woman of Samaria is set in the historical and cultural context. Therefore, it is necessary to ask about the religious experience of the woman (knowledge and faith), since this factor was crucial for the comprehension and acceptance of the revelation of Jesus as Messiah (4:25-26) and the only Saviour of the world (4:41-42).

\section{The Narrative Strategy in John 4:1-26}

There exist multiple narrative models of the pericope in John $4: 1-42 .{ }^{6}$ Frédéric Manns postulates the concentric structure with the central moment of the story in verses 19-26. ${ }^{7}$ The proposed composition is transparent, though it should be slightly modified, particularly with respect to the opening situation, considering the parallel use of the same form of the verb है $\rho \chi \mu \alpha \mathrm{r}$ in reference to Jesus and the woman of Samaria (verse 5 and verse $7 a$ ). ${ }^{8}$ This stylistic device is used by the author to accentuate the two main protagonists of the story. Having noticed this element, one can delineate the structure of the pericope as follows:

A. 1-7a: Towards Galilee going through Samaria

B. 7b-15: Jesus asks the Samaritan woman for water to drink. The dialogue about the two "waters"

C. 16-18: Jesus speaks about the Samaritan woman

D. 19-26: The revelation of Jesus' identity. Worship in Spirit and in truth

C'. 27-30: The Samaritan woman bears witness about Jesus

B'. 31-38: Disciples ask Jesus to eat something. The dialogue about the two types of "food"

A'. 39-42: Towards Galilee

6 For instance, Henryk Witczyk ("Jezus przynosi Ewangelię Samarii (J 4,1-42)," VV 10 [2006] 117) asserts that the pericope in John 4:1-42 follows the principle of a diptych with an introduction: 4:1-6 setting of the dialogue between Jesus and the woman of Samaria, (I) 4:7-26 - the dialogue between Jesus and the woman of Samaria / Jesus is the Sower, (II) 4:27-42 - the dialogue between Jesus and his disciples / Jesus and disciples as Harvesters; Jesus recognised as the Saviour of the world. Meanwhile, Stanisław Mędala (Ewangelia wedlug świętego Jana. I. Rozdzialy 1-12 [NKB.NT 4/1; Częstochowa: Edycja Świętego Pawła 2010] 453) divides the story into the introduction (4:1-6), two scenes of the dialogue with the woman of Samaria (4:7-15, 4:16-26), the conversation between Jesus and his disciples (4:27-38) and the epilogue that speaks of the faith of the Samaritan woman (4:39-42). A similar structure was presented by Francis J. Moloney (Il Vangelo di Giovanni [SP 4; Leumann: Elledici 2007] 100,110 ) who identifies two parallel dialogues in the first section of the story: 4:7-15 and 4:16-30.

7 The author divides the text into the following units: A. 1-6; B. 7-15; C. 16-18; D. 19-26; C'. 27-30; B'. 31-38; A'. 39-42. Manns, L'Evangile, 124-125.

8 Regarding the beginning of the section, see also: M. Marcheselli, "Il motivo del tempio in Gv 2-4. Un sondaggio su un punto sensibile della ipotetica teologia sostitutiva del quarto Vangelo," Israele e Chiesa nel Vangelo di Giovanni. Compimento, reinterpretazione, sostituzione? (ed. M. Marcheselli) (Bologna: EDB 2016) 52. 
The composition of the story is exemplary. It should be analysed with reference to the stages which make up any story: (1) the opening situation - (2) the problem - (3) the turning point / the climax - (4) the denouement / the solution - (5) the final situation. ${ }^{9}$ One must bear in mind that the smaller units of a story, especially at the stage of problem presentation and denouement, can have their own composition, thereby creating a narrative within a narrative. It is clearly seen in section B which forms the first part of the complication and drives the dynamics of the entire story. ${ }^{10}$ The indicated problem is then developed and deepened in section $\mathrm{C}$. These both sections contain crucial elements which allow the reader to reach the proper solution and discover the theological message intended by the author.

The structure of section B is concentric and its individual parts are marked by the initiating phrases which contain the verb $\lambda \dot{\varepsilon} \gamma \omega$ : four times in the third person singular in the present tense (verses $7 \mathrm{~b}, 9,11,15$ ) and twice in the aorist of

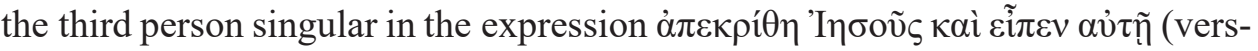
es 10 and 13). ${ }^{11}$ The last part a' belongs to the next section C. ${ }^{12}$ It is an example of interrelated narratives ${ }^{13}$ :

a. 7b-c: Jesus ( $\lambda \dot{\varepsilon} \gamma \varepsilon 1 \alpha \nu \jmath \tilde{)})$

"Give me to drink."

(v. 8: background)

b. 9: SAMARITAN WOMAN ( $\lambda \dot{\gamma} \gamma \varepsilon l$ oũv $\alpha$

"How is it that You, a Jew, ask a drink of me, a woman of Samaria?"

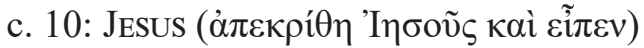

"If you knew the gift of God, and who it is that is saying to you, 'Give Me a drink,' you would have asked Him, and He would have given you living water."

9 Marguerat - Bourquin, Per leggere, 50. There are various story models. Some of them are presented by Jean-Louis Ska in "I nostri padri ci hanno raccontato". Introduzione all'analisi dei racconti dell'Antico Testamento (Bologna: EDB 2012) 38-63.

10 At this stage of the story, there appears a dramatic tension related to a difficulty, a conflict, an accident or an obstacle which is necessary for the subsequent solution of the problem as intended by the author. See Marguerat - Bourquin, Per leggere, 50.

11 Stanisław Mędala (Ewangelia, 456-457) indicates that "the expression beginning with apekrithen accentuates the ceremonial and official nature of the utterance." The author also explains that the ex-

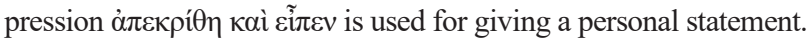

12 See a similar structure postulated by Raymond Edward Brown (The Gospel According to John I-XII [AB 29; New York: Doubleday 1966] 176-177).

13 Interrelated or interconnected narratives have frequent occurrences in the Bible. They are structured in such a way that the ending of one episode is the starting point for the next episode. Such transitions come as a surprise to the reader and make the action more dynamic, while the entire event is presented in a new light and opens up new possibilities for interpretation. In consequence, the reader is able to delve into deeper layers of meaning in the text. See more on this topic: Marguerat - Bourquin, Per leggere, 63-65. These authors describe this literary device as "trame imbricate." 
d. 11-12: SAMARITAN WOMAN ( $\lambda \varepsilon ́ \gamma \varepsilon l ~ \alpha v ं \tau \tilde{)})$

"Sir, are You greater than our ancestor Jacob, who gave us the well?"

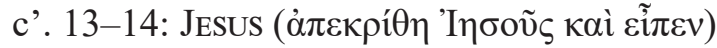

"The water that I will give will become in them a spring of water gushing up to eternal life."

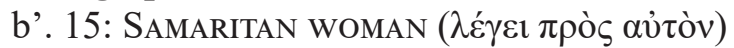

"Sir, give me this water, so that I may never be thirsty!"

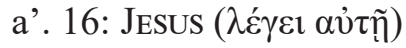

"Go, call your husband, and come back."

This structure of the story reveals several turning points and a well-planned strategy:

A. Initially, Jesus asks the woman to "give Him to drink," while at the end she asks Jesus for the living water (verse $7 \mathrm{~b}-\mathrm{c} /$ verse 15).

B. Initially, the Samaritan woman sees Jesus only as a Jew, but then she recognizes Him as the Lord (verse 9 / verses 11 and 15).

C. The turning point of the entire story can be identified in Jesus' words about knowing the gift of God. This motif gives the woman of Samaria and each reader of FG an insight into the real identity of Jesus, Messiah, who is the Source of life (verse 10).

D. The author uses irony. As a result, the words of the Samaritan woman in verses 11-12 are revelatory (Jesus is someone greater than the patriarch Jacob).

E. What allows to reach the deepest theological message is the motif of the gift of God which emerges in the context of Jacob's well and the living water springing upwards.

F. The initial request expressed by Jesus ("Give me to drink") should not be interpreted literally, but in the light of the device of misunderstanding that is typical of FG. This request is transferred to another level in the dialogue between Jesus and the Samaritan woman, first in section B, then in section C (verse 16: "Go, call your husband, and come back"). ${ }^{14}$

The above analysis of the narrative strategy in John 4:7b-15 leads to the conclusion that in order to find the right meaning of the event and show its theological links with the entire FG, one must answer these two questions:

i. Who was the woman of Samaria?

ii. Why did Jesus, Messiah, reveal His identity at Jacob's well and how does this motif relate to the Passover which is the direction of the entire narrative in FG?

14 There is no uniform exegetical approach to the use of misunderstanding and irony in FG. With respect to John 4:1-42, one may adopt the stance of those scholars who postulate the presence of these two rhetorical techniques in the entire story. See B.J. Malina-R.L. Rohrbaugh, Social-science Commentary on the Gospel of John (Minneapolis, MN: Fortress 1998) 102-103. 


\section{2. "A Samaritan woman came to draw water" - the Cultural Context}

The story of Jesus' encounter with the woman of Samaria contains numerous details which reveal the cultural and religious context. First of all, the reader learns that the event took place while Jesus was travelling through Samaria, in the city of Sychar, by Jacob's well (verses 5-6a).

Until the time of king Solomon (i.e. mid-10 century BC), Samaria was a geographical region inhabited mainly by two tribes of Israel: the tribe of Manasseh and the tribe of Ephraim. The division which ultimately led to the emergence of a separate political structure had intensified through many centuries and reached its climax in the 8 century $\mathrm{BC}$, during the expansion of the Neo-Assyrian Empire. ${ }^{15}$ It was then that the Syro-Ephraimite alliance against Assyria led to a dire conflict with Ahaz, king of Judah. After the fall of Samaria in 722 BC, it became a province of Assyria and many Samaritan Jews were deported to the territory of Mesopotamia. ${ }^{16}$ From then on the social structure of Samaria started changing due to the influx of culturally foreign masses of people. Still, many inhabitants of Samaria descended from the line of proto-Samaritans. Faced with difficulties related to rebuilding the temple in Jerusalem, this section of the society decided to erect their own sanctuary on Mount Gerizim. The relations between Jews (especially Jews from Judah) and Samaritans probably started deteriorating from this moment onward, and the tension reached its culmination after John Hyrcanus destroyed the temple on Mount Gerizim in 128 BC. ${ }^{17}$ The Book of Sirach can be brought in as evidence.

When analysing the Greek version of Sir 50:25-26, Jolanta J. Pudełko notices the essential difference in relation to the original Hebrew text (manuscript B)

15 A synthetic approach to this topic can be found in H. Thyen, Studien zum Corpus Iohanneum (Tübingen: Mohr Siebeck 2007) 483-500.

16 See W. Chrostowski, Asyryjska diaspora Izraelitów i inne studia (RiSB 10; Warszawa: Vocatio 2003) 37-39. There are abundant sources on this topic, including polemics against the actual existence of the Assyrian diaspora. A discussion between Waldemar Chrostowski and Wojciech Pikor is worth mentioning in the context of Polish research. See W. Pikor, "W poszukiwaniu asyryjskiej diaspory Izraelitów w Księdze Ezechiela," BibAn 2/1 (2012) 27-74, and the reply titled "Asyryjska diaspora Izraelitów w świetle Księgi Ezechiela. Wojciechowi Pikorowi w odpowiedzi”: W. Chrostowski, Trzecia Światynia w Jerozolimie i inne studia (RiSB 44; Warszawa: Vocatio 2012) 108-166.

17 Mirosław S. Wróbel (Antyjudaizm a Ewangelia wedlug św. Jana [Lublin: Wydawnictwo KUL 2005] 205) describes Samaritans in the following manner: "Samaritans depreciated the role of David and his dynasty. They did not attach any great significance to Jerusalem and Judah, therefore they resolutely rejected the term «Jews» in the context of their identity. Though Flavius Josephus says that

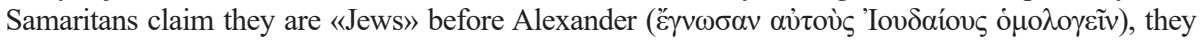

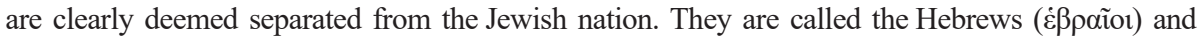
the Kuttim, as a foreign people that came to Samaria." 
which consists in two references to Samaritans. The Greek text (2/1 century BC) speaks of those "settled on Mount Samaria" (the Hebrew versions refers to "people living in Seir") and of "people that dwell in Shechem". ${ }^{18}$ According to J.J. Pudełko, the first reference indicates the dignitaries from the city on Mount Shomron belonging to Shemer, which functioned as the capital city of the district of Samaria during Persian times. It was a place known for religious syncretism due to many centuries of infiltrating pagan cults. ${ }^{19}$ In contrast, the "people that dwell in Shechem" are Samaritans who believe in YHWH and have their place of worship on Mount Gerizim as well as Jews from Judah who have joined Samaritans for various reasons, but mainly due to the dissatisfaction with the situation in the south of the country. ${ }^{20}$ The scholars locate Jacob's well in this territory and the Syrian translation of FG even reads Shechem instead of Sychar. ${ }^{21}$

18 J.J. Pudełko, "Powstanie Samarytan a ich obraz w Syr 50,25-26," WST 33 (2015) 179-184.

19 This is, of course, a serious oversimplification, since the native (Jewish) people of Samaria and migrants from Mesopotamia quickly merged. Furthermore, there were frequent changes in the political strata in this territory. For instance, Stanisław Wypych ("Samarytanie w ujęciu historycznym, geograficznym i religijnym," $R B L 3$ [2005] 175) indicates that in Persian times the ruling class in Samaria worshipped YHWH, as evidenced by the names given to children and by the fact that Jews from the Egyptian diaspora (5 century BC) asked the leaders in Jerusalem and in Samaria for assistance in rebuilding the temple on Elephantine.

20 See Pudełko, "Powstanie Samarytan," 183-184. There is an ongoing discussion on the identity of the peoples living in Samaria from the 8 century BC to the 1 century AD. In an extremely interesting study of the image of Samaritans in the writings of Flavius Josephus, Reinhard Pummer presents the views of the researchers of antiquity with respect to the inhabitants of Samaria in the Persian, Hellenic and Roman periods. The author assumes that not all people living in Samaria in those times were, in statu nascendi, descendants of proto-Samaritans who had believed in YHWH. He deems it justified to make the distinction between Samarians and Samaritans, as introduced by Hans G. Kippenberg. From this perspective, Samarians were people who identified with the capital of the district, Samaria, for political reasons (usually they had come to Samaria from other regions), while Samaritans were the ethnic inhabitants of Samaria or migrants from Judah who had their place of worship on Mount Gerizim. Reinhard Pummer asserts that though this distinction may seem artificial, it sheds a new light on some Biblical passages. He believes that one must not confuse Samaritans, who had worshipped YHWH for many centuries, with descendants of pagans who had arrived in Samaria from Mesopotamia in the 8 century BC. The general religious syncretism of this social group has nothing in common with the faith of those who traced their lineage to Manasseh and Ephraim as well as of those believers in YHWH who later came from Judah or Galilee to settle in Samaria. For this reason, it is advisable to distinguish between Samarians and Samaritans. Incidentally, it seems that the natives of Samaria never referred to themselves as Samaritans (שומרונים). The name is recorded only once in the Old Testament, in 2 Kings 17:29, with reference to the religious syncretism after the Assyrian conquest in 722 BC. Until the present times, Samaritans have preferred the name of שמרים , i.e. "Guardians of the Torah" or "Guardians of the land of Israel." This name can be found in the writing of Origen (ca. 185-254 AD), but it may date back to earlier times. Following this lead, R. Pummer emphasises that any Biblical passage containing the proper name of the inhabitants of

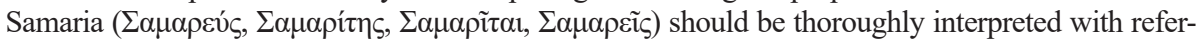
ence to the context. See R. Pummer, The Samaritans in Flavius Josephus (TSAJ 129; Tübingen: Mohr Siebeck 2009) 5-8.

21 The reading $\Sigma^{\prime} \chi \alpha \rho-69 v^{\mathrm{cl.ww}}{ }^{\mathrm{mos}}{ }^{\mathrm{ms}}$; the reading $\Sigma v \chi \varepsilon \dot{\varepsilon} \mu-\mathrm{sy}^{\mathrm{s.c}}$. 


\section{3. "How is it that You, a Jew, ask a drink of me, a woman of Samaria" - the Religious Context}

Though the precise location of the encounter between Jesus and the woman of Samaria has never been identified, it was undoubtedly nearby Mount Gerizim. This is confirmed by the woman's words about the worship "on this mountain" in contrast to the worship at the temple in Jerusalem (John 4:20). If this be so, then the religious message of Judaism could also reach Mount Gerizim. ${ }^{22}$ The religion of Samaritans was based on four pillars: (1) the worship of YHWH; (2) the sacrificial cult on Mount Gerizim; (3) the recognition of the continuity of the Levitical priesthood only with respect to their own priests; (4) the use of the Pentateuch in a slightly modified version. ${ }^{23}$ It is also highly probable that various Biblical traditions, including midrashim and targumim, disseminated throughout Samaria and found their way into the Samaritan synagogal liturgy. ${ }^{24}$ It should be noted here that at the turn of the eras Samaritans had their own synagogues which imitated the Jewish model. ${ }^{25}$ It is known that in the 4 century AD the Samaritan religious leader called Baba Rabba was the moving force behind the reorganization of the religious cult in Samaritan communities, which, among other changes,

22 Interestingly, the passage of 2 Maccabees 5:22-33, dated to the period after $124 \mathrm{BC}$, which describes the barbaric actions taken by Antiochus IV Epiphanes towards Jews, mentions Mount Gerizim. It follows that at this time the inhabitants of Samaria who worshipped on this mountain were deemed a part of the Jewish nation. Similar conclusions may be drawn from 2 Maccabees 6:1-2. The passage speaks of the simultaneous profanation of two temples: in Jerusalem and on Mount Gerizim. The fact that these two places, commonly (and stereotypically) held to be the source of the conflict between Jews and Samaritans, appear next to each other is a proof that at the turn of the 2 century BC the inhabitants of Samaria who worshipped God on Mount Gerizim were included in the Jewish community (2 Maccabees 6:2b might seem to contradict this assumption, but R. Pummer [Samaritans, 12-15] believes it is a later gloss added to the manuscript under the influence of the views held by Flavius Josephus).

23 See M. Rosik, Kościół a Synagoga (30-313 po Chr.) na rozdrożu (Wrocław: Chronicon 2016) 132.

24 The Samaritan targumim were studied in the 1980s by Avraham Tal. This scholar asserts that they date back to the period between the end of the 1 century BC and the 11 century AD. See I. Hjelm, The Samaritans and Early Judaism. A Literary Analysis (JSOTSup 303; Shefield: Sheffield Academic Press 2000) 86. Reinhard Pummer holds a slightly different view: "As to Samaritan sources, the Pentateuch is our only early literary source. Apart from it, short inscriptions from Mt. Gerizim and from the Greek island of Delos have been unearthed; and from the third or fourth century C.E. we have the Aramaic Targum of the Samaritan Pentateuch. The earliest liturgical and midrashic texts date from the fourth century C.E. Most of the other extant Samaritan literature comes from the Middle Ages and later periods" (R. Pummer, "Samaritans, Galileans, and Judeans in Josephus and the Gospel of John," JSHJ 18/1 [2020] 82).

25 There are numerous publications on this topic. See e.g.: R. Pummer, "Samaritan Synagogues and Jewish Synagogues. Similarities and Differences," Jews, Christians, and Polytheists in the Ancient Synagogue. Cultural Interaction During the Greco-Roman Period (ed. S. Fine) (London - New York: Routledge 1999) 118-160, and the updated version: R. Pummer, "Samaritan Synagogues and Jewish Synagogues: A New Look at their Differentiating Characteristics," The Samaritans in Historical, Cultural and Linguistic Perspectives (ed. J. Dušek) (SJ 110; Berlin: De Gruyter 2018) 51-74. 
resulted in the reopening of synagogues. However, synagogues had existed in Samaria much earlier, as evidenced by ancient synagogal inscriptions dated to the 1 century AD and by the collection of 23 liturgical hymns (Durran) closely related to the ancient liturgy of the synagogues. ${ }^{26}$ Like in Judaism, there existed the Samaritan Targum of the Pentateuch (hereinafter: ST) and one of its manuscripts was purchased by Pietro della Valle in 1616 from the Samaritan community in Damascus. It was then brought to Rome. ${ }^{27}$ The origin and dating of ST are probably similar to the Jewish targumim. ${ }^{28} \mathrm{ST}$ was written in Aramaic. However, it does not contain any midrash additions that can be found in the Palestinian targum tradition, therefore it follows a conception that is analogous to Targum Onkelos. ${ }^{29}$ In this context, one should bear in mind that there is no information on how targumim actually functioned within the earlier oral tradition and to what extent the folk traditions widespread in Palestine were used in the interpretation of the Samaritan Pentateuch.

The passages of 2 Macc 5:22-33, 6:1-2 and the dialogue between Jesus and the woman of Samaria can be seen as proof that the split between Jews and the inhabitants of Samaria could be moderate (towards Samaritans worshipping YHWH on Mount Gerizim) and radical (towards the political elites which, despite the centuries that had passed, could still be identified with the descendants of the peoples from Mesopotamia and their religious syncretism). ${ }^{30}$ There is no

26 See H.G. Kippenberg, "I Samaritani," Testi giudaici per lo studio del Nuovo Testamento (eds. H.G. Kippenberg - G.A. Wewers) (NovTSup 8; Brescia: Paideia 1987) 126. Regarding the various opinions on the dating of the Durran texts, some of which move the origin of particular hymns to the 1-2 centuries AD, see M. Kartveit, The Origin of the Samaritans (VTSup 128; Leiden - Boston: Brill 2009) 296.

27 This manuscript dates back to 1514. See A. Tal, "The Samaritan Targum to the Pentateuch, Its Distinctive Characteristic and Its Metamorphosis," JSS 21 (1976) 26. This is not the only extant transcript of ST. See J.A. Montgomery, The Samaritans - the Earliest Jewish Sect. Their History, Theology and Literature (Philadelphia, PA: Winston 1907) 290.

28 Montgomery, Samaritans, 292. This author dates ST to the 3-4 centuries AD. However, it should be noted the 20 century saw new discoveries (especially in Qumran) which significantly broadened the horizons in the studies of the origin of the targum tradition. At present, there is evidence of written targumim down as early as the 2 century BC. See A. Tronina, "Najstarsze thumaczenia Pięcioksięgu," CT 69/1 (1999) 56; M.S. Wróbel, Wprowadzenie do Biblii Aramejskiej (BAram; Lublin: Gaudium 2017) 65-67.

29 See Tal, "The Samaritan Targum," 32. This author points out that on the basis of the available documents, one can surmise that the targum literature in the Samaritan communities evolved in exactly the same manner as in the Jewish communities, where it is possible to identify two groups of targumim: the Palestinian targumim which contained translations of the Bible as well as midrashim and glosses (Targum Neofiti 1, Targum Pseudo-Jonathan and other fragments) and the Babylonian targumim which contained a faithful translation of the Pentateuch into Aramaic (Targum Onkelos). Louis H. Feldman (“Judaizm palestyński i diaspory I wieku," Chrześcijaństwo a judaizm rabiniczny. Historia początków oraz wczesnego rozwoju [ed. H. Shanks] [PB 2; Warszawa: Vocatio 2013] 46) observes that Samaritans had one thing in common with the Sadducees: they rejected the oral Torah.

30 In one of his prolegomena to the topic of Mesopotamian migrants in Palestine, W. Chrostowski notices that the fate of the peoples deported to the conquered territories of Israel and Samaria during the Assyrian invasion in the 8 century BC is not really clear: "We cannot say what happened to 
doubt that at the turn of the eras the relations between Jews and Samaritans were extremely tense ${ }^{31}$ Apart from a long history of animosities, the additional flashpoint was the profanation of the temple in Jerusalem in $6 \mathrm{BC}$ by a group of Samaritans who scattered human bones in the courtyard. ${ }^{32}$

\section{4. "If you knew the gift of God" - the Indirect Allusion as the Hermeneutic Key in the Narrative of John 4:7b-15}

Considering the complex relations between Jews and Samaritans, any common ground for dialogue seems impossible. ${ }^{33}$ However, the history of the split between the two nations had preserved some shared ideas which Jesus used to make the woman of Samaria capable of recognising His identity. The common thread for at least some strata in the Samaritan communities and Jews was the faith in

the Mesopotamian people forced to settle in Palestine and to their descendants. It may be surmised that those of the Babylonian lineage who witnessed the fall of Assyria (612 BC) could take some advantage from the events related to the Babylonian invasions and the conquest of Judah by Nebuchadnezzar II in 605 BC. (...) We do not know if [in the Persian period - added by the author] the descendants of the Mesopotamians deported by Sargon II were still there and had been assimilated by the local people, finally losing their original identity, or if they survived in the alien environment or if they chose or were forced to emigrate, perhaps to Babylonia" (W. Chrostowski, Babilońskie deportacje mieszkańców Jerozolimy i Judy oraz inne studia [RiSB 34; Warszawa: Vocatio 2009] 34). In the context of the diversity of the population in Samaria at the turn of the eras, one can verify how Samaritans were portrayed in the New Testament, particularly in the Gospel of Luke (the Gospel of Mark does not mention Samaritans at all, while the Gospel of Matthew contains only one reference related to the mission of the Twelve in 10:5, when the apostles are told not to visit any Samaritan cities). Luke mentions Samaritans on three occasions: Luke 17:11-19-the healed Samaritan gives praise to God, but it is not said where he is supposed to do it (he could belong to the Samaritans worshipping on Mount Gerizim); Luke 10:30-37 - the Samaritan "had compassion" (in the Gospels the word $\sigma \pi \lambda \alpha \gamma \chi v i \zeta o \mu \alpha$ refers to mercy as one of the attributes of YHWH that should also be cultivated by His people); Luke 9:52 in a negative context - the rejection of Jesus who travelled to Jerusalem for the Passover (this can be a hint at the rivalry between Mount Gerizim and the temple in Jerusalem).

31 A very pertinent summary of this situation is presented by John P. Meier ("The Historical Jesus and the Historical Samaritans: What can be Said?", Bib 81 [2000] 216-218). He points out that in fact Samaritans (proto-Samaritans) never merged with Jews into one homogeneous organism, be it geographically, ethnically and religiously, especially that the very word "Jew" (יהודי) derives from the name of the descendants of the southern tribe of Judah, focused around Jerusalem and the temple cult, while Samaritans belonged to the peoples of the north. According to Meier, it is advisable to assume that at the turn of the eras Samaritanism and Judaism were two separate branches of the ancient religion of Israel, the religion of Palestine, which had at its core the faith in YHWH as the One and Only God in line with the message of the Torah.

32 See Rosik, Kościót,131-132.

33 See Meier, "Historical Jesus," 227-230. A thorough analysis of the relations between Samaritans and Jews from Galilee and Judah in the 1 century AD was performed by R. Pummer. His final conclusion is that the tension between Samaritans and Jews was not so serious as to exclude any type of relations. See Pummer, "Samaritans, Galileans," 97-99. 
YHWH and the Pentateuch as the normative book of religion. Regarding Biblical figures, Samaritans manifested special reverence for Moses, the greatest of the prophets, and for Jacob's son, Joseph, who was the father of Ephraim. ${ }^{34}$ Following the passage of Deut 18:15-19, they expected the coming of the "new Moses" at the end of times, the eschatological figure of Taheb, and following the message of Gen 37:5-11 and Gen 41:40-43, they recognised Joseph as king in opposition to the tradition of David. ${ }^{35}$ Reminiscences of both figures can be found in the dialogue between Jesus and the woman of Samaria.

The text of John 4:7b-15 is a fragment of a larger story and has previously been defined as a narrative within a narrative. It reveals a concentric composition and consists of five sections:

$\mathrm{a}$ - the initial situation / exposition: verses $7 \mathrm{~b}-\mathrm{c}$

$\mathrm{b}$ - the problem: verses $8-9$

c-d-c' - the turning point / climax: verses 10-14

b' - the resolution: verse 15

a' - final situation: verse 16

The dialogue between Jesus and the Samaritan woman is preceded by a relatively long exposition (4:1-7) which establishes the setting of the story. From the perspective of narratology, it is simply the moment when the protagonist and the antagonist enter the stage along with the introduction of secondary characters and the general background. In the passage of $4: 1-7 \mathrm{a}$, the protagonist (Jesus) and the antagonist (the woman of Samaria) are introduced with the use

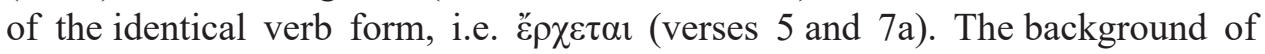
the story covers: (a) Samaria, (b) the city of Sychar, (c) Jacob's well, (d) Joseph, son of Jacob (verses 4-6). Additionally, the narrator underlines that Jesus travels through Samaria on His way from Judah to Galilee. The implicated transition is from the temple in Jerusalem to the pagan or quasi-pagan region, since that was the perception of the inhabitants of northern Israel by pious Jews, particularly by the Pharisees (mentioned in verse 1 and belonging to the passive characters in the narrative).$^{36}$ The Samaritan context is important, but it can be seen only when the reader "breaks" the rules of narratology and steps outside the text itself. It

34 In "Memar Marqah," a Samaritan text dated to circa 4 century AD, the figures of Moses the prophet and Joseph the king are portrayed together. See more on the topic: A.D.A. Moses, Matthew's Transfiguration Story and Jewish-Christian Controversy (JSNTSup 122; Sheffield: Sheffield Academic Press 1996) 67-74; Wróbel, Antyjudaizm, 205; Rosik, Kościót, 132-133; D.C. Mitchell, Messiah Ben Joseph (Newton Mearns: Campbell Publication 2016) 263.

35 "Taheb shall come in peace to rule the place chosen by God for pious people [...]. Joseph came and rewarded with a kingdom after the imprisonment, and those who had persecuted him, received his grace. [...] There is no other like Joseph the king and like Moses the prophet" (Memar Marqah IV, 12). Wróbel, Antyjudaizm, 205.

36 The meeting at Jacob's well may also be seen as the prefiguration of the words of Caiaphas and the related commentary by the author of FG in John 11:51-52. Jesus is revealed as the principle of unity. 
is not a coincidence that the narrator makes Jacob's well the meeting place of Jesus, a Jew, and the woman of Samaria. He refers to the times when there was no division between Jews and Samaritans (see Gen 28:1-30:24). ${ }^{37}$ However, at that time there existed other divisions, often caused by competing for fertile pastures or access to sources of water. In fact, these two motives emerge in the story in John 4:1-42, and one of them (Jacob's well) is specifically important, since it was at this well that Jacob met Rachel, his wife to be (Gen 29:1-11) and mother of Joseph (Gen 30:22-24).

At the same well, Jesus meets the woman of Samaria who comes to the well to quench her thirst, as Rachel did long time before her. The narrative in John 4:7b-15 has the form of a dialogue and its consecutive stages are marked by

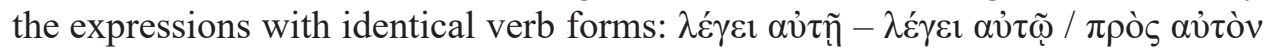

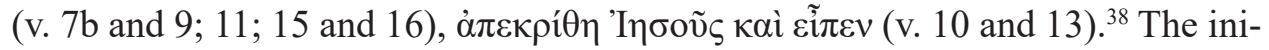
tial situation when Jesus asks the woman of Samaria to give Him water to drink (7b-c) evolves dynamically in her reply and the narrator's comment (9), reaching the climax in Jesus' utterance about the living water and knowing the gift of God (10) and in the question asked by the woman: "Sir, are You greater than our ancestor Jacob?" (11-12). ${ }^{39}$ It is a moment when the author assumes that the reader has wide knowledge of the context, since without it the hidden meaning of the story remains obscure. ${ }^{40}$

Genesis 28-29 describe the meeting of Jacob and Rachel at the well, but both Hebrew Bible (BH) and Samaritan Pentateuch (SP) do not contain the two essential elements: the gift of God and the living water which allow the Samaritan woman to accept the gift of Jesus, i.e. the source of life (v. 15) and to confess: "He cannot be the Messiah, can he?" (v. 29). Both versions of the Pentateuch only confirm the fact that Jacob's well actually existed. It was an important source of water, so the access was strictly regulated by its owner (see Gen 29:7-9).

37 Analogies can be found in the Bible. For example, when the Book of Ruth reaches its culmination point and Boaz intends to marry Ruth the Moabite (Ruth 4:11-13), the inhabitants of Bethlehem wish to win God's favour for Boaz and refer in their prayers to the times of Rachel and Lea, before Moab was cursed (see Num 25).

38 See more on the use of the literary dialogue form in John 4:1-42: V. Mannucci, Giovanni il Vangelo narrante. Introduzione all'arte narrativa del quarto Vangelo (Bolonia: EDB 2016) 47.

39 In his extended commentary to FG, Hartwig Thyen (Das Johannesevangelium [HNT 6; Tübingen: Mohr Siebeck 2005] 249) writes that verse 10 marks the transition to a new level of the narrative: "Darum können wir in den vermeintlichen «Brüchen» und «Spannungen» in der Erzählung nicht Eröffnung der Lizenz zur Literarkritik sehen. Vielmehr müssen wir versuchen, solche Leerstellen und Spannungen als «dramaturgische Mittel» der Darstellung zu begreifen, die den Leser nötigen, die Textkohärenz durch seine Lektüre erst herzustellen. In diesem Licht erscheint auch V. 10 keineswegs als ein Bruch, sondern als die kunstvolle Weiterführung des begonnenen Gesprächs auf einer neuen Ebene."

40 Bogusław Górka (Jezus i Samarytanka, 66) writes: "The name of Jacob's ground can indeed be deduced from the Biblical tradition, but the same cannot be said about Jacob's well or source." 
Scholars take different paths to reach the message of the dialogue in which Jesus focuses on the motif of the living water as the gift of God. To comprehend this symbol, apart from theological intertextual links within FG, one should analyse the targum tradition where Jacob's well becomes associated with God's intervention. ${ }^{41}$ Targum Neofiti 1 (TN) contains a midrash depicting Jacob's travel from Beersheba to Haran where five signs/miracles occurred. This motif was often analysed by such scholars as José Ramón Díaz, ${ }^{42}$ Martin McNamara, ${ }^{43}$ F. Manns, ${ }^{44}$ Roger Le Déaut, ${ }^{45}$ Craig A. Evans,${ }^{46}$ Mirosław S. Wróbel. ${ }^{47}$ However, this phenomenon can be studied from a different methodological perspective. It seems that so far exegetes have failed to fully appreciate the special significance of the targum tradition in the entire narrative. ${ }^{48}$ Meanwhile, it is only the additional layer of the meta-text that makes it possible to reveal the hidden sense of the event, bearing in mind that FG must be interpreted at various levels. ${ }^{49}$ The motif of Jacob's well and the gift of God seems most closely related to the targum tradition in TN Gen 28:10 and 29:1.4-10, though some scholars also indicate the possible connections with TN Num 21:16-18. Furthermore, semantic aspects require a deeper analysis as much as the theological aspects.

41 This is not a new topic. There is an extensive study by Jerome H. Neyrey („Jacob Tradition and the Interpretation of John 4:10-26," CBQ 41 [1979] 419-437).

42 J. Ramón Díaz, "Palestinian Targum and New Testament," NovT 6 (1963) 76-77.

43 M. McNamara, Targum and Testament (Shannon: Irish University Press 1972) 145-146.

44 Manns, L'Evangile, 127-135.

45 R. Le Déaut, “Targum," Supplément au Dictionnaire de la Bible (eds. J. Briend - M. Quesnel) (Paris: Letouzey \& Ané 2002) XIII, 290-293.

46 C.A. Evans, Ancient Texts for New Testament Studies. A Guide to the Background Literature (Peabody, MA: Hendrickson 2005) 211.

47 Wróbel, Wprowadzenie, 289-290.

48 Indeed, one should mention the publication by B. Górka (Jezusi Samarytanka, 71-104) where the links between FG and the targum tradition are studied more widely, but it does not exhaust the discussion on the topic. Regarding the comments to FG, only some of them draw on the Jewish traditions with respect to the Jacob's cycle, but without any closer analysis of these texts. A good example is the commentary by Xavier Léon-Dufour (Lettura dell'evangelo secondo Giovanni [Cinisello Balsamo: San Paolo 2007] 307) who writes: "Se l'evangelista usa qui il termine «sorgente» (pēgē), lo fa probabilmente per preparare l'annuncio della sorgente che disseta per sempre; il termine tuttavia potrebbe anche evocare un miracolo attribuito a Giacobbe: secondo una leggenda rabbinica, il patriarca avrebbe fatto salire, fino a traboccare oltre la vera del pozzo, un'acqua sovrabbondante. Sullo sfondo del racconto giovanneo vi sono probabilmente diverse tradizioni su Giacobbe, conosciute dai lettori contemporanei di Gv." See also: Thyen, Johannesevangelium, 244, 250; Ch.K. Barrett, Das Evangelium nach Johannes (Göttingen: Vandenhoeck \& Ruprecht 1990) 250; R.E. Brown, An Introduction to the Gospel of John (ABRL; New York: Doubleday 2003) 136-137. This approach is justified by the late dating of the available versions of targumim and midrashim.

49 It is sufficient to refer to the book by Gerry Wheaton (The Role of Jewish Feasts in John's Gospel [SNTSMS 162; Cambridge: Cambridge University Press 2015] 66-76) on the Jewish feasts in FG. The author analyses John 4:1-42 as the wedding metaphor, but the lack of references to nonBiblical Jewish literature leads to serious difficulties in the interpretation of the symbol of the "living water." 
TN Gen 28:10 contains a description of Jacob's travel from Beersheba to Haran when "five signs were made (חמשה נסין אתעבדו)." The verb עבד is used here in the mediopassive voice, which means that the action is not made by Jacob, but by God Himself. This acting subject is confirmed by the Aramaic noun נס which denotes "a miracle" or "a sign" in Palestinian targumim and in most cases it indicated God's act through which He reveals Himself to people. This noun can be found in $\mathrm{TN}$ in several significant passages:

i. TN Gen 21:1: "The Lord made signs unto Sarah (ועבד ייי ניסין לשרה)" - this passage speaks of "signs" which meant that Sarah became pregnant and bore a son to Abraham;

ii. TN Exod 8:18: "I shall make signs and miracles (ואעבד ניסין ופליין) on that day in the land of Goshen, in which my people dwell"- this is the announcement of the miraculous intervention in which YHWH reveals to the Pharaoh that only YHWH is the Lord of all creation and wields Power above all powers;

iii. TN Exod 10:1: "The Lord said unto Moses: «Go in unto Pharaoh (...), that I might shew these my signs among them (למשוויה ניסיא איליין ביניהון)»" this passage refers to the signs made to the Pharaoh before Jews departed from Egypt;

iv. TN Exod 15:18: "Sons of Israel said: «Lord, how the royal crown befits You! When Your sons saw the signs of Your miracles (ניסי פרישתך) in the seas and Your power among the waves...»" - it is a fragment of the hymn that Moses and the people of Israel sang in the context of the Passover after crossing the Red Sea;

v. TN Deut 4:33-34: "Which people or kingdom did hear the voice of the Memra of the living Lord speaking out in the midst of the fire as thou hast heard, and live? Or the signs which the Lord made to take Him a nation from the midst of another nation amidst signs, wonders and wondrous events (בניסן באתין ובפרישן) (...)?"- it is a fragment of Moses' speech where he praises the choice of Israel as God's people. Notably, the Aramaic text has three expressions for wondrous signs, while BH uses two nouns: אות and מופת: "Has any god ever attempted to go and take a nation for himself from the midst of another nation, by trials, by signs and wonders (באתת ובמופתים), by war (...)?" This passage is particularly significant due to the lexical similarity between $\mathrm{TN}$ and $\mathrm{BH}$.

The above targumim speaking of signs / wonders indicate that the noun נס occurs in the context of various interventions made by God in the history of the people and is often linked to the Passover, the Exodus and the Covenant. This aspect is important with respect to the narrative in John 4:1-42. It is contained in the first part of the Gospel of John $(2: 1-12: 36)$ which is referred to by many 
exegetes as the "Book of Signs." 50 The well where Jesus talks to the woman of Samaria witnessed the "sign" that God had made centuries ago to the patriarch Jacob. According to TN, this sign (the fifth and the last one) was as follows: when Jacob moved the stone from the mouth of the well, water sprang out and filled the well throughout the entire stay of Jacob in Haran, i.e. for twenty years (TN Gen 28:10; 29:1.4-10). ${ }^{51}$

Another interesting aspect is the semantic relation between Jesus' words about

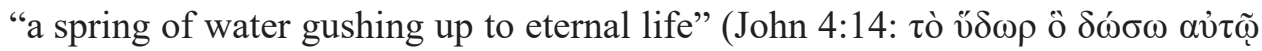

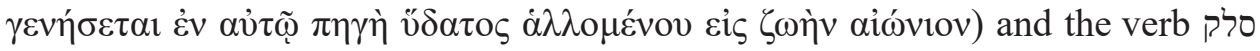
used in TN Gen 28:10 with reference to the water which filled Jacob's well in Haran. ${ }^{52}$ The verb סלק suggests the idea of an upward movement, ascending, reaching a higher level..$^{53}$ In Greek, it is usually translated with verbs which denote

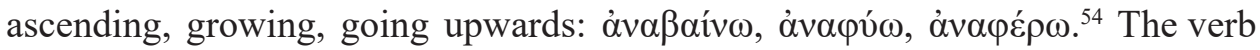
$\ddot{\alpha} \lambda \lambda$ ou $\alpha \mathrm{r}$ used in John 4:14 has a similar meaning. In LXX, it denotes such actions as "jumping up" (1 Sam 10:2; Isa 35:6) or "jumping over" (1 Sam 10:10) or "reaching a goal" (Wis 5:21). In the New Testament, the verb appears in John 4:14 and in Acts 3:8; 14:10, always denoting the upward movement (jumping). When comparing the targumim with LXX, we do not find any direct rela-

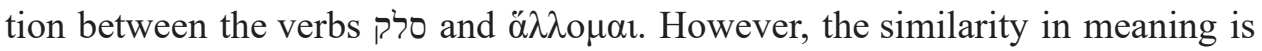
obvious. Both verbs express the idea of an upward movement which can be more or less rapid or sudden.

The extensive paraphrase in TN Gen 28:10 is complemented with the variant of TN Num 21:16-18. This passage describes the journey of the Israelites from Egypt to Canaan. The author speaks of the last stage of the road near Beer. It was there that God had promised to provide the Israelites with water from an ancient well (BH Num 21:16: "From there they continued to Beer; that is the well of which the LORD said to Moses: «Gather the people together, and I will give them water [ואתנה להם מים]»"). Thus, the well in Beer was associated with the gift of God at the time the Book of Numbers was written. This motif is later developed

50 See G. Mlakuzhyil, The Christocentric Literary Structure of the Fourth Gospel (AnBib 117; Roma: PIB 1987) 137-241. An interesting rhetorical structure of John 2:13-12:50 is described by S. Mędala. He provides this section with the following title: "Authentication of the mystery of the Son of Man - argumentation based on testimonies and signs." The first smaller unit within the section is John 2:13-10:42 which the author defines as "Testimonies and signs before the «hour»" (see Mędala, Ewangelia, 94).

51 See M.S. Wróbel, Targum Neofiti 1. Księga Rodzaju. Tekst aramejski-przektad-aparat krytycznyprzypisy (BAram 1; Lublin: Gaudium 2014) 265.

52 See P. Kot, Targumy a Pierwszy List św. Jana. Literacko-teologiczne zwiąki tradycji targumicznej o Kainie i Ablu (TNRdz 4,1-17) z Pierwszym Listem św. Jana (RiSB 38; Warszawa: Vocatio 2010) 74.

53 See M. Sokoloff, A Dictionary of Jewish Palestinian Aramaic of the Byzantine Period, 2 ed. (DTMT 2; Jerusalem: Bar Ilan University Press 1992) 379-380.

54 Cf. T. Muraoka, A Greek-Hebrew/Aramaic. Two-way Index to the Septuagint (Louvain: Peeters 2010) 291. 
by the author of the targum who links the well with the great patriarchs of Israel, including Jacob: "The well that was dug by the princes of the world from the beginning: Abraham, Isaac and Jacob." Then the text adds that Moses and Aaron measured the well with their staffs and it was (or the water) the gift in the wilderness: "From the wilderness they were giventhe gift" (ומן מדברה אתיהבת להון מתנה). The noun נתן etymologically derives from the root (infinitive), so it can be translated as "something given." In LXX, this word is translated as a proper

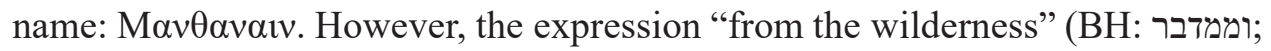

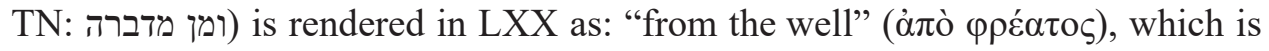
logical in terms of etymology. To gather these various nuances together, we look at the following versions:

i. BH: From the wilderness [they went] to Mattanah (...);

ii. LXX: From the well [they went] to Manthanain (...);

iii. TN: From the wilderness they were given the gift.

The analyses performed above allow to draw the conclusion that the two passages of the Palestinian targum, TN Gen 28:10;29:1.4-10 and TN Num 21:16-18, complement one another in the depiction of Jacob's well as the gift from God. This gift consisted in that regardless of the season the well in the wilderness was full of water springing up from the clear source. It was a sign similar to those that occurred later in Egypt before the Exodus and similar to the miracle that Jews saw when crossing the Red Sea on foot: the sign of God's presence in the history and of the abundance of His kindness and grace.

In John 4:1-42, Jesus sits at the same well of Jacob and points out the continuity between His presence and the experience of Israel in the past. ${ }^{55}$ The dialogue indicates that the woman of Samaria who comes to the well must have known the non-Biblicaltexts (targumim or similar) about Jacob. Only this can explain the fact that she was so quick in understanding Jesus' allusion and immediately desired to change the water from the well to what she saw in that man (4:29) who came (see है $\rho \chi \varepsilon \tau \alpha$ in 4:25 in the context of Taheb) and revealed to her the truth about her life. ${ }^{56}$

55 Léon-Dufour, Lettura dell'evangelo, 509.

56 Referring to the targum traditions related to Jacob's well, H. Thyen (Johannesevangelium, 244) writes: "Nach Pirqe Abot V/9 exiestierte der wunderbare Brunnen, der die Väter auf ihren Reisen und das Volk auf seiner Wanderung durch die Wüste begleitete schon vor Grundlegung der Welt. Paulus

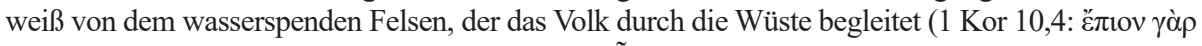

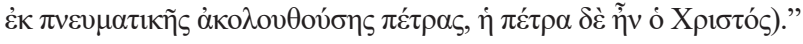




\section{Conclusion}

If the woman of Samaria had known the story of Jacob only from SP, she could have heard in Jesus' words an attempt to show the superiority of Jews over Samaritans. This is implicated in her question: "Are You greater than our ancestor Jacob?" (4:12). Meanwhile, Jesus used a "method" which the Samaritan woman must have known from the synagogal liturgy. In line with the practice which emerged in the synagogues probably around the 5 century $\mathrm{BC}$, theology "descended" among the listeners through targumim and midrashim. ${ }^{57}$ Therefore, Jesus at Jacob's well can be seen as a peculiar Meturgamen who introduces a woman having no knowledge of the Prophets or the Scriptures to the most profound mystery of God's revelation, adapting the message to her level of faith and knowledge. ${ }^{58}$ At the same time, Jesus leads the dialogue based on the motif that was equally significant to both Jews and Samaritans.

In this context, one faces the question regarding the purpose of using such a method in FG. One of the possible answers is the hypothesis asserting that the Gospel of John was addressed to the inhabitants of Samaria so that they could accept the gift of Jesus Christ - in whom everything was fulfilled - that God had announced in the history of Jacob, Joseph and Moses. ${ }^{59}$ In order to achieve this purpose, it was necessary to establish a common space of dialogue which would overcome the gaps resulting from many centuries and would open onto a specific

57 There is an ongoing and active discussion regarding the date and the geographical context of the establishment of the synagogue as an institution. Some scholars locate its origin in Judah (and/or Samaria), while others seek its beginnings in Greek-speaking diasporas. There are also other theories related to the Jewish diaspora in Mesopotamia.

58 There are various attempts at solving the issue of the conversation between Jesus and the Samaritan woman in relation to the theology presented in the Gospel of John. Many exegetes interpret the metaphors used in John 4 in the light of the prophetic and wisdom texts. That is the approach of Andrea Taschl-Erber ("Christological Transformation of the Motif of «Living Water» (John 4:7). Prophetic Messiah Expectations and Wisdom Tradition," Reading the Gospel of John's Christology as Jewish Messianism. Royal, Prophetic, and Divine Messiahs [eds. B.E. Reynolds - G. Boccaccini] [AJEC 106; Leiden - Boston: Brill 2018] 248-270). However, a question must be asked regarding the Samaritan woman's knowledge of the Old Testament prophetic and wisdom books. It seems that the mutual understanding evident in the dialogue is mainly based on the context of the Pentateuch and related sources. Of course, the immediate problem pertains to the sources. The premise formulated above does not exclude other criteria of interpretation. It should always be remembered that the Gospel of John has multiple layers of signification and wide theological connotations.

59 See more on FG as the Samaritan gospel in: E.D. Freed, "Did John Write His Gospel Partly to Win Samaritan Converts?," NovT 12 (1970) 241-256; J.D. Purvis, "The Fourth Gospel and the Samaritans," NovT 17 (1975) 161-198; Witczyk, "Jezus," 115-137; F.T. Gench, Encounters with Jesus. Studies in the Gospel of John (Louisville, KY - London: Westminster John Knox Press 2007) 31; M.S. Wróbel, Studia z Ewangelii Janowej (W Kręgu Słowa 5; Tarnów: Biblos 2009) 37-42; J. Beutler, Das Johannesevangelium. Kommentar (Freiburg im Breisgau: Herder 2013) 168; Mędala, Ewangelia, 149, $169-170$. 
novum. Though the idea of FG as the so-called Samaritan gospel has not been commonly accepted, one cannot ignore the meanings that emerge from the analysis of John 4:1-1560:

i. Jesus revealed that $\mathrm{He}$ is greater than Jacob, for when this patriarch stayed in the wilderness, he could rely only on the kind gift from God, while Jesus was Himself the source of life, the Giver and the gift;

ii. Jesus "came" to Samaritans as Messiah (verse 5), which was exactly what they had been expecting (cf. the Aramaic Taheb);

iii. By referring to the events from the history of salvation and to the promise given to people in consequence of their sin, Jesus reveals that $\mathrm{He}$ is the fulfillment of that promise.

Perhaps the author of FG included the story of the encounter between Jesus and the Samaritan woman in the Gospel in order to convey the message about the universal salvation which formed a great challenge in the 1 century AD, especially in the context of the Jewish exclusivity. However, this aspect does not exhaust the message of the story. There are also other important points to the story:

i. Jesus reveals the mystery of His person in relation to the history of salvation which had always been developing in such a way as to open the way for Jesus;

ii. He is Himself God's sign / gift that is given to people so that they can find their way to salvation ${ }^{61}$;

iii. The sign of the abundance of water in Jacob's well prefigured the gift of life-giving grace for whom will believe that Jesus is Messiah.

In John 4:7b-15, the water from the well is the antithesis of the living water. In turn, the living water is the symbol of life which Jesus possesses, being one with the Father, and also of the Holy Spirit. It is the Holy Spirit which will later become the gift from the resurrected Christ. ${ }^{62}$ Owing to Him, the new life in the believers will be continually supported and reinforced until it reaches its completion in the resurrection to the eternal life. ${ }^{63}$ By knowing the non-Biblical texts about Jacob's well and through the symbolism of the living water, the woman of Samaria is elevated to a different level of "seeing" Jesus. This is

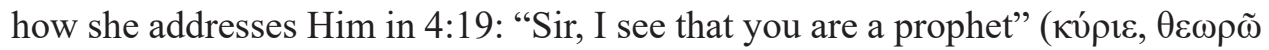

60 See J. Beutler, L'Ebraismo e gli Ebrei nel Vangelo di Giovanni (SubBi 29; Roma: PIB 2006) 108-109.

61 A sign from God is always a provocation and a challenge. It requires that the person who receives and accepts it should leave the beaten track and enter a new path of a full life which is in line with God's intentions. This is clearly seen in the negative example of king Ahaz (Isa 7:10-14) who rejected the sign from God and very quickly lost his freedom.

62 Henryk Witczyk ("Jezus," 125) asserts that "«the gift of God» and «the living water» (...) form a parallel structure," therefore "they signify the same reality." The author believes that the living water denotes "the grace of Truth which is Jesus Himself, His presence and His teaching."

63 See R.A. Culpepper, Anatomia del Quarto Vangelo. Studio di critica narrativa (Milano: Glossa 2016) 268-269. 


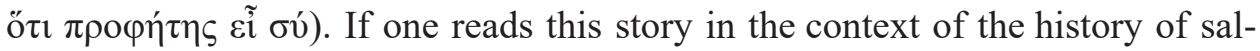
vation, this confession becomes a kind of fulfillment of what God promised to Abraham and his offspring in Gen 12:1. Now the Lord said to Abram: "Go from your country (...) to the land that I will show you" (this translation is acceptable due to the use of the verb ראה in Hifil). It is the ability of a trustful perception of the world around and the entire history with the faith that God fulfills His promises. That is how Abraham experiences his trial in the land of Moriah (see Gen 22:8.14). Now the woman of Samaria received a "vision" of Jesus in whom all God's promises were fulfilled. She understood that the place where she stood was not a coincidence. In consequence, she was able to recognize the sign which was revealing its meaning before her. The unquenchable thirst, the memory of God's gift and the words spoken by Jesus allowed the woman of Samaria to see Jesus is the completion of the entire history and that He is indeed greater than Jacob and Moses. That is how she saw the truth: Jesus is Messiah (4:25).

When reading the story about the encounter of Jesus and the woman of Samaria, one must bear in mind that Jesus is the key protagonist, not the woman. Though the historical context evoked by the narrative helped the woman recognise the mysterious gift of God in Jesus, from the beginning of the story, including the section 4:7b-15, all elements directly lead to the confession that Jesus is the Only Lord, Messiah and Saviour of the world (4:42). ${ }^{64}$ Jesus is the Saviour $(\sigma \omega \tau \eta ি \rho)$, which means that He is the Source of life that never dries up. He is a gift of God for everyone who will believe that He has been sent by God, that He is "one with God" (John 10:30; 17:11.21), and that He came to give "life to the world" (John 6:33). The reference to Jacob's well in Jesus' conversation with the woman was addressed mainly to Samaritans who believed in YHWH and knew the history of salvation, but needed to openly accept the "true gift of God," Jesus Christ, to make their lives complete. Jesus also made a call of faith to other inhabitants of Samaria who worshipped alien gods, but he did it using a different argument, which is included in verses 4:16-19. ${ }^{65}$ The woman speaking to Jesus believed in YHWH, but she also lived a life of idolatry (she had many husbands). As such, she symbolises all inhabitants of Samaria. The author of FG introduces her to his text to formulate a clear message: the Gospel can become a source of life for everybody. One must only have faith and accept the "gift of God" in the person of Jesus Christ.

64 See Mędala, Ewangelia, 474. One should also bear in mind the Chrystological and the Ecclesiological interpretations. From this perspective, the story reveals the figure and the prefiguration of the new Covenant, the new marriage of sinful people (Bride, i.e. the Church) with Christ (Beloved). 


\section{Bibliography}

Barrett, Ch.K., Das Evangelium nach Johannes (Göttingen: Vandenhoeck \& Ruprecht 1990).

Beutler, J., Das Johannesevangelium. Kommentar (Freiburg im Breisgau: Herder 2013).

Beutler, J., L'Ebraismo e gli Ebrei nel Vangelo di Giovanni (Subsidia Biblica 29; Roma: PIB 2006).

Brown, R.E., An Introduction to the Gospel of John (Anchor Bible Reference Library; New York: Doubleday 2003).

Brown, R.E., The Gospel According to John I-XII (Anchor Bible 29; New York: Doubleday 1966).

Chrostowski, W., Asyryjska diaspora Izraelitów i inne studia (Rozprawy i Studia Biblijne 10; Warszawa: Vocatio 2003).

Chrostowski, W., Babilońskie deportacje mieszkańców Jerozolimy i Judy oraz inne studia (Rozprawy i Studia Biblijne 34; Warszawa: Vocatio 2009).

Chrostowski, W., Trzecia Światynia w Jerozolimie i inne studia (Rozprawy i Studia Biblijne 44; Warszawa: Vocatio 2012).

Culpepper, R.A., Anatomia del Quarto Vangelo. Studio di critica narrativa (Milano: Glossa 2016).

Díaz, J.R., "Palestinian Targum and New Testament," Novum Testamentum 6 (1963) 75-80.

Evans, C.A., Ancient Texts for New Testament Studies. A Guide to the Background Literature (Peabody, MA: Hendrickson 2005).

Feldman, L.H., "Judaizm palestyński i diaspory I wieku," Chrześcijaństwo a judaizm rabiniczny. Historia początków oraz wczesnego rozwoju (ed. H. Shanks) (Podręczniki Biblijne 2; Warszawa: Vocatio 2013) 25-87.

Freed, E.D., "Did John Write His Gospel Partly to Win Samaritan Converts?," Novum Testamentum 12 (1970) 241-256.

Gench, F.T., Encounters with Jesus. Studies in the Gospel of John (Louisville, KY - London: Westminster John Knox Press 2007).

Górka, B., Jezus i Samarytanka(J 4,1-42). Historia i inicjacja(Kraków: WAM 2008).

Hjelm, I., The Samaritans and Early Judaism. A Literary Analysis (Journal for the Study of the Old Testament Supplement Series 303; Shefield: Sheffield Academic Press 2000).

Hudry-Clergeon, Ch., "De Judée en Galilée. Étude de Jean 4,1-45," Nouvelle revue théologique 103 (1981) 818-830.

Jędrzejewski, S., "Pochodzenie synagogi," Ruch Biblijny i Liturgiczny 63/4 (2010) 315-325.

Kartveit, M., The Origin of the Samaritans (Supplements to Vetus Testamentum 128; Leiden - Boston: Brill 2009).

Kippenberg, H.G., "I Samaritani," Testi giudaici per lo studio del Nuovo Testamento (eds. H.G. Kippenberg - G.A. Wewers) (Supplements to Novum Testamentum 8; Brescia: Paideia 1987) 117-141.

Kot, P., Targumy a Pierwszy List św. Jana. Literacko-teologiczne zwiazki tradycji targumicznej o Kainie i Ablu (TNRdz 4,1-17) z Pierwszym Listem św. Jana (Rozprawy i Studia Biblijne 38; Warszawa: Vocatio 2010).

Kręcidło, J., Nowe życie uczniów Jezusa. J 21 jako owoc eklezjologicznej relektury J 1-20 we wspólnocie Umiłowanego Ucznia (Rozprawy i Studia Biblijne 33; Warszawa: Vocatio 2009).

Le Déaut, R., “Targum,” Supplément au Dictionnaire de la Bible (eds. J. Briend - M. Quesnel) (Paris: Letouzey \& Ané 2002) XIII, 1-344.

Léon-Dufour, X., Lettura dell'evangelo secondo Giovanni, 2nd ed. (Cinisello Balsamo: San Paolo 2007). 
Malina, B.J. - Rohrbaugh, R.L., Social-science Commentary on the Gospel of John (Minneapolis, MN: Fortress 1998).

Manns, F., L'Evangile de Jean à la lumière du Judaïsme (Studium Biblicum Franciscanum Analecta 33; Jerusalem: Franciscan Printing Press 1991).

Mannucci, V., Giovanni il Vangelo narrante. Introduzione all'arte narrativa del quarto Vangelo (Bolonia: EDB 2016).

Marcheselli, M., "Il motivo del tempio in Gv 2-4. Un sondaggio su un punto sensibile della ipotetica teologia sostitutiva del quarto Vangelo," Israele e Chiesa nel Vangelo di Giovanni. Compimento, reinterpretazione, sostituzione? (ed. M. Marcheselli) (Bologna: EDB 2016) 37-69.

Marguerat, D. - Bourquin, Y., Per leggere i racconti biblici. La Bibbia si racconta. Iniziazione all'analisi narrativa, 2nd ed. (Roma: Borla 2011).

McNamara, M., Targum and Testament (Shannon: Irish University Press 1972).

Meier, J.P., "The Historical Jesus and the Historical Samaritans: What can be Said?," Biblica 81 (2000) 202-232.

Mędala, S., Ewangelia wedtug świętego Jana. I. Rozdziały 1-12 (Nowy Komentarz Biblijny. Nowy Testament4/1; Częstochowa: Edycja Świętego Pawła 2010).

Mitchell, D.C., Messiah Ben Joseph (Newton Mearns: Campbell Publication 2016).

Mlakuzhyil, G., The Christocentric Literary Structure of the Fourth Gospel (Analecta Biblica 117; Roma: PIB 1987).

Moloney, F.J., Il Vangelo di Giovanni (Sacra pagina 4; Leumann: Elledici 2007).

Montgomery, J.A., The Samaritans- the Earliest Jewish Sect. Their History, Theology and Literature (Philadelphia,PA: Winston 1907).

Moses, A.D.A., Matthew's Transfiguration Story and Jewish-Christian Controversy (Journal for the Study of the New Testament Supplement Series 122; Sheffield: Sheffield Academic Press 1996).

Muraoka, T., A Greek-Hebrew/Aramaic. Two-way Index to the Septuagint (Louvain: Peeters 2010).

Neyrey, J.H., "Jacob Tradition and the Interpretation of John 4:10-26," Catholic Biblical Quarterly 41 (1979) 419-437.

Pikor, W., "W poszukiwaniu asyryjskiej diaspory Izraelitów w Księdze Ezechiela," Biblical Annals 2/1 (2012) 27-74.

Pudełko, J.J., "Powstanie Samarytan a ich obraz w Syr 50,25-26," Warszawskie Studia Teologiczne 33 (2015) 168-187.

Pummer, R., "Samaritan Synagogues and Jewish Synagogues: A New Look at their Differentiating Characteristics," The Samaritans in Historical, Cultural and Linguistic Perspectives (ed. J. Dušek) (Studia Judaica 110; Berlin: De Gruyter 2018) 51-74.

Pummer, R., "Samaritan Synagogues and Jewish Synagogues. Similarities and Differences," Jews, Christians, and Polytheists in the Ancient Synagogue. Cultural Interaction During the Greco-Roman Period (ed. S. Fine) (London - New York: Routledge 1999) 118-160.

Pummer, R., "Samaritans, Galileans, and Judeans in Josephus and the Gospel of John," Journal for the Study of the Historical Jesus 18/1 (2020) 77-99.

Pummer, R., The Samaritans in Flavius Josephus (Texts and Studies in Ancient Judaism 129; Tübingen: Mohr Siebeck 2009).

Purvis, J.D., “The Fourth Gospel and the Samaritans,” Novum Testamentum 17 (1975) 161-198.

Rosik, M., Kościół a Synagoga (30-313 po Chr.) na rozdrożu (Wrocław: Chronicon 2016). 
Ska, J.-L., "I nostri padri ci hanno raccontato". Introduzione all'analisi dei racconti dell'Antico Testamento (Bologna: EDB 2012).

Sokoloff, M., A Dictionary of Jewish Palestinian Aramaic of the Byzantine Period, 2nd ed. (Dictionaries of Talmud, Midrash and Targum 2; Jerusalem: Bar Ilan University Press 1992).

Tal, A., "The Samaritan Targum to the Pentateuch, Its Distinctive Characteristic and Its Metamorphosis," Journal of Semitic Studies 21 (1976) 26-38.

Taschl-Erber, A., "Christological Transformation of the Motif of «Living Water» (John 4:7). Prophetic Messiah Expectations and Wisdom Tradition," Reading the Gospel of John's Christology as Jewish Messianism. Royal, Prophetic, and Divine Messiahs (eds. B.E. Reynolds - G. Boccaccini) (Ancient Judaism and Early Christianity106; Leiden - Boston: Brill 2018) 248-270.

Thyen, H., Das Johannesevangelium (Handbuch zum Neuen Testament 6; Tübingen: Mohr Siebeck 2005).

Thyen, H., Studien zum Corpus Iohanneum (Tübingen: Mohr Siebeck 2007).

Tronina, A., "Najstarsze thumaczenia Pięcioksięgu," Collectanea Thelogica 69/1 (1999) 47-62.

Wheaton, G., The Role of Jewish Feasts in John's Gospel (Society for New Testament Studies Monograph Series 162; Cambridge: Cambridge University Press 2015).

Witczyk, H., “Jezus przynosi Ewangelię Samarii (J 4,1-42)," Verbum Vitae 10 (2006) 115-137.

Wróbel, M.S. (ed.), Targum Neofiti 1. Księga Rodzaju. Tekst aramejski-przekład-aparat krytyczny-przypisy (Biblia Aramejska 1; Lublin: Gaudium 2014).

Wróbel, M.S., Antyjudaizm a Ewangelia wedtug św. Jana (Lublin: Wydawnictwo KUL 2005).

Wróbel, M.S., Studia z Ewangelii Janowej (W Kręgu Słowa 5; Tarnów: Biblos 2009).

Wróbel, M.S., Wprowadzenie do Biblii Aramejskiej (Biblia Aramejska; Lublin: Gaudium 2017).

Wypych, S., "Samarytanie w ujęciu historycznym, geograficznym i religijnym," Ruch Biblijny i Liturgiczny 58/3 (2005) 165-179. 